\title{
COMMUNICATING CSR ON TOURISM INDUSTRY; A PRELIMINARY CASE STUDY OF BALI
}

\author{
Kadek Dwi Cahaya Putra, I Komang Mahayana Putra, \\ A.A.A. Mirah Kencanawati \\ Business Administration Department, Bali State Polytechnic \\ Jalan Bukit Jimbaran, Jimbaran, Badung, Bali. \\ Telp.0361.701981 / E-mail: dwicahayaputra@pnb.ac.id
}

\begin{abstract}
As one of the world's and Indonesia's most important tourist destination, Bali tourism sector has significantly contributed to both Indonesia's and Bali's economy. This study explores how tourism companies communicate CSR including goals, audiences, contents, channels, and strategy. Data are gathered through a single case study approach and thirteen semi-structured interviews to the representatives of hotels, restaurants, tour and travels, and tourism companies in Bali. Data are analyzed by using QDA Miner software. The result shows that relationships, reputation, and branding are the most common goals of communicating CSR. The companies communicated mostly to internal stakeholders; employees and owner, to customers, and the local community. However, there was no specific policy on contents. The companies use reports, meeting, announcement board, e-mail, and in-house communication system to communicate with internal stakeholders; social media, employee, and CSR involvement to communicate with customers; and newspaper, social media, TV, meeting, and employee to communicate to society. An involving strategy was prevalently used mainly through dialogic meeting with the employees and the local community.
\end{abstract}

Keywords: Corporate Communication, CSR, Strategy, Tourism industry.

\begin{abstract}
Abstrak
Sebagai salah satu tujuan wisata paling penting di dunia dan Indonesia, sektor pariwisata Bali telah memberikan kontribusi yang signifikan bagi perekonomian Indonesia dan Bali. Studi ini mengeksplorasi bagaimana perusahaan pariwisata mengkomunikasikan CSR termasuk tujuan, khalayak, konten, saluran, dan strategi. Data dikumpulkan melalui pendekatan studi kasus tunggal dan tiga belas wawancara semi-terstruktur dengan perwakilan hotel, restoran, wisata dan perjalanan, dan perusahaan pariwisata di Bali. Data dianalisis menggunakan perangkat lunak QDA Miner. Hasilnya menunjukkan bahwa hubungan, reputasi, dan branding adalah tujuan paling umum dari komunikasi CSR. Perusahaan-perusahaan sebagian besar berkomunikasi dengan pemangku kepentingan internal; karyawan dan pemilik, kepada pelanggan, dan masyarakat setempat. Namun, tidak ada kebijakan khusus mengenai konten. Perusahaan menggunakan laporan, rapat, papan pengumuman, email, dan sistem komunikasi internal untuk berkomunikasi dengan pemangku kepentingan internal; keterlibatan media sosial, karyawan, dan CSR untuk berkomunikasi dengan pelanggan; dan surat kabar, media sosial, TV, rapat, dan karyawan untuk berkomunikasi dengan masyarakat. Strategi komunikasi yang lazim digunakan yaitu "involving"; terutama melalui pertemuan dialogis dengan karyawan dan masyarakat setempat.
\end{abstract}

Kata Kunci: Corporate Communications, CSR, strategi, industri pariwisata.

\section{Introduction}

In today's business where stakeholders not only demand companies to conduct Corporate Social Responsibility (here after abbreviated as CSR) but also to provide data and information about its scopes, quantity, progress, and achievements (de Grosbois, 2012, p.898), communicating CSR should be a common practice. CSR is successful when it is both well implemented 
and communicated (Du, Bhattacharya, \& Sen, 2010) because CSR would only be beneficial if it is well communicated to relevant stakeholders (Maignan \& Ferrell, 2004). Communicating CSR in tourism is important but challenging due to the multiple business sectors and stakeholders involved. CSR in tourism is better understood by a description of the types of activity it may or should entail in the sector (Coles, Fenclova, \& Dinan, 2013). By communicating CSR, the companies explain a new sustainability policy and gain reputation to minimize negative impacts during a crisis and to highlight responsible business practice (Graci \& Dodds, 2008), create a competitive edge for new employees, and enhance image for CSR conscious potential consumers (J. L. Holcomb, Upchurch, \& Okumus, 2007).

However, tourism companies have less drive to communicate CSR; due to low quality and usability, low adoption, varied data, and information with regard to its scope and depth for different companies (de Grosbois, 2015), and difficulty of using it for external evaluation and comparison (Seyitoglu \& Yuzbasioglu, 2015). A study involving 239 global tourism companies from 10 business sectors indicated that the practice lags behind other industries, as only $31 \%$ companies provided sustainability information on their websites and only $19 \%$ had a stand-alone CSR report (Herremans, Pyasi, \& Lu, 2011). Communicating CSR is generally more apparent in large companies while the tourism industry is mostly made up of small and medium-sized enterprises (SMEs) (Tamajón \& Aulet, 2013). There is also a wide gap in practice among business sectors where accommodation has more efforts than others. Consequently, research on communicating CSR in tourism seems to be critically new and limited (Coles et al., 2013; J. L. Holcomb et al., 2007), slow and in steady progress (Ricaurte, 2012), and much focused on accommodation sector than tour and travel, restaurants, airlines, and tourist attractions. CSR has become a communication challenge (Dawkins, 2005).

Companies communicate CSR to multiple stakeholders through varied methods and multiple channels which have led to being possibly "counterproductive and fragmented" regarding consistency and coordination of communication" (Cornelissen, 2014, p. 5; van Riel \& Fombrun, 2007). Corporate communication is a "management function that offers a framework for the effective coordination of all internal and external communication with the overall purpose of establishing and maintaining reputable reputations with stakeholder groups upon which the organization is dependent" (Cornelissen, 2014, p.5). Corporate communication "embraces all communication processes, which contribute to tasks, its implementation within companies and contribute to the internal and external coordination of actions and the clarification of interests defining the relation between companies and specific stakeholders" (Zerfass, 2008, p. 66).

Corporate Communication integrates internal communication, marketing communication and public relations to communicate with internal, market, and 
society-based stakeholders (Zerfass, 2008). Internal stakeholders' CSR awareness is very important because it represents an essential element of external communication, representation and image of the company as they are information transmitters to the external environment (Bhattacharya, Sen, \& Korschun, 2008). Building relation with market-based stakeholders is also important because greater than $80 \%$ customers believed firms should engage in social initiatives and $76 \%$ felt those initiatives would benefit firms (Becker-Olsen, Cudmore, \& Hill, 2006). Besides, "any and every marketing communications tool is capable of conveying a company's CSR message and contributing to its corporate image and brand equity" (Jahdi \& Acikdilli, 2009, p. 106). Public Relations focuses on relationships and balancing interests and expectations between organizations and their stakeholders, society and shapes organizational policy and activity as well as public understanding of the organizations (Bartlett, 2011) through specific functions of and roles such as community relations, media relations, government relations, and issue management (Fawkes, 2004).

Communicating CSR relates to any communication that is designed and distributed by the company itself about its CSR efforts (Morsing, 2006) which involve goals, audience, contents, and channels (Coombs \& Holladay, 2012; Du et al., 2010). It is unique because it has many potential audiences (Dawkins, 2005) so that companies must adapt to the specific needs of different stakeholders due to their varied business expectations, information needs, and may respond differently to the various channels (Du et al., 2010). A study involving hotel, airlines and tour and travel sector indicated that each sector has different prioritized stakeholders (World Travel \& Tourism Council (WTTC), 2015). The report showed that airline companies mostly communicate CSR to customers, employees, and investors, followed by shareholders, governments supply chain, communities, and NGOs. On the other hand, hotel companies communicate to employees, customers, and supply chain, followed by shareholders, communities, owners, investors and NGOs, business organizations and business partners. Tour operators provide CSR information to employees, supply chain, customers, NGOs, shareholders, investors, and governmental organizations as well as to business organizations, business partners, communities, and society.

Content means CSR information to communicate. CSR in tourism relates to "business responsibility for the natural environment, employees, tourists, partners and businesses in the supply chain, the local community in the destination as well as the society as a whole based on the triple bottom line approach" (Lund-durlacher \& Brewi, 2014). The most applied framework of CSR content especially in the tourism industry worldwide is the G4 GRI reporting standard (Global Reporting Initiative (Global Reporting Initiative, 2015). The framework consists of three main CSR themes such as the economy, environment, and social with its four sub-themes such as labor practice, 
human rights, society, and product and responsibility. However, different business sectors in tourism tend to communicate different CSR contents.

A study of 150 global hotel companies showed that environment content was disclosed by 61 companies, employment quality by 71 , diversity accessibility by 36 , society/community well-being by 72 , and economic prosperity by 46 companies(de Grosbois, 2012). This indicates that information on community and employment quality are very important for hotel companies to communicate. Similarly, a study of 10 global hotel companies indicated that community is the area where most hotel companies concentrate their efforts when reporting their philanthropic activities being a highly publicized company, slightly followed by 'diversity' category either it applies to employees (J. L. Holcomb et al., 2007).

The study showed that $80 \%$ of companies reported socially responsible activities relating to some forms of charitable donation but reported less on the aspects of the environment, vision, and values. There were $60 \%$ companies reported having a diversity policy about suppliers/business partners as well as employees, $50 \%$ companies supported employee volunteer program and $40 \%$ of the companies provided social responsibility statements in their vision, mission and other documents (Holcomb et al. 2007).

In tour and travel sector, a study of 42 international companies indicated how the contents are mostly focused on internal management issues, customer relations, product management and development, supply chain management and cooperation with destinations (Wijk \& Persoon, 2006). Theme park companies generally provided contents related to the environment, community, market-place, and employees (J. Holcomb, Okumus, \& Bilgihan, 2010). In Indonesia, stakeholders perceived that CSR contents should relate to products, energy, other information, sustainability, human resources, environment, external relation, and community (Gunawan, 2008).

Studies on channels of communicating CSR are mostly on how companies provide CSR information on the websites, social media, and annual or CSR report with less attention given to the use of print media, electronic media and face to face meeting. de Grosbois (2012) found four ways of how global hotel companies provide CSR information on the website; (1) with a downloadable CSR or environmental report or section of the annual report devoted to CSR; often also using other methods of communication, (2) with CSR devoted section of their website, often also using other methods of CSR communication, but with now downloadable CSR or environmental report nor CSR-specific section of their annual report, (3) with no explicit website or report addressing CSR, but providing some CSR information in other sections of the website and (4) with no information regarding their impacts of CSR efforts provided. Wong, Leu, and Law (2015)'s similar study of 124 hotels in Hongkong showed that the hotels prefer to use social 
media of Facebook than a website. The study showed that $49 \%$ did not provide CSR info on the website, $27 \%$ provided CSR info, and $36 \%$ use social media of Facebook as a method to disclose CSR information to stakeholders.

Facebook was more preferred because it costs much less than a website. Kim \& Ferguson (2014) divided CSR communication channels into controlled and uncontrolled. Their study among US customers showed that they prefer companycontrolled media such as companies' local stores, websites, and promotional events to uncontrolled media such as news media, expert blogs and microblogs. More studies are still required for the use of other channels than website and reports to communicate CSR such as print media, electronic media, face to face meetings and social media.

Morsing \& Schultz (2006)argued that "stakeholders" CSR expectations are a moving target and may change over time so that must be considered carefully on a frequent basis" (p.1). Therefore, companies need to apply a stakeholder communication strategy of informing, responding, and involving strategy (Morsing and Schultz, 2006). Informing is based on oneway communication principle aimed at disseminating information, not necessarily with a persuasive intent, but rather to inform the public as objectively as possible about an organization. CSR communication is how you inform, persuade and celebrate your CSR programs (Crane \& Glozer, 2016).

Responding is based on the twoways communication approach of not only communicate CSR but also attempt to get feedback from stakeholders because the companies expect their CSR to be acceptable and beneficial. This strategy sees communication itself as feedback and an evaluate mode of measurement in the attempt to find out what the public will accept, tolerate and whether a communication initiative has improved understanding of the company, by conducting, usually, opinion poll or a market survey (Morsing and Schultz, 2006). However, although the responding strategy is based on a twoways communication approach, it can not create a balanced relationship because the stakeholders' response is not influential yet.

Companies attempt to involve stakeholders through dialogue and negotiation to always keep updated with their expectations, and to influence those expectations. Involving strategy is a dialogue, persuasion, and two-ways based communication in which both the companies and stakeholders have the rights to change or influence and also to be changed or be influenced (Morsing and Schultz, 2006). Through this strategy, companies expect to develop, promote and adopt two-ways supports through frequent and systematic companies - stakeholder engagement and dialogues to explore mutually beneficial actions (Morsing and Schultz, 2006). An effective dialogue can create effective decision making, stakeholder engagement, improve corporate governance, maximize stakeholders' perceptions of legitimacy and trust (Golob, Podnar, Nielsen, Thomsen, \& Elving, 2015). 
Corporate communication on CSR is worth studying because dealing with sustainable development, and social responsibility has been of strategic communication challenge (Holtzhausen \& Zerfass, 2011). Communicating CSR in tourism helps to explain to employees and support the roll-out of a company's new sustainability policy, reputation for crisis resilience, to highlight responsible business practice across a company's worldwide operations (Graci \& Dodds, 2008). Based on the theory description above, a conceptual model of how tourism companies communicate CSR is set up. Companies use corporate communication to communicate CSR; internal communication, marketing communication, and public relations. Internal communication is used to build relationships with internal stakeholders, marketing communication is with marketbased stakeholders, and public relations builds relationships with society-based stakeholders.

Communicating CSR involves goals, audiences, content, and channel with a stakeholder communication strategy. Initially, the companies setup communication goals which strategically link with the company's business goals. After that, the companies identify specific stakeholders as the target audience. Then, the companies specific select CSR contents, channels, and stakeholder communication strategy to communicate to the already identified audiences. In other word, companies set up communication goals, identify and prioritize stakeholders (audience), selecting CSR information the stakeholders are concerned on (content), and selecting channels with a stakeholder communication strategy.

As in other destinations in developing nations, CSR plays a very important role for Bali, Indonesia. CSR helps the Bali tourism companies to gain legitimacy or license to operate in the society and branding or marketing advantages (Dewi, Mataram, \& Siwantara, 2017; Mahyuni, 2013). CSR is not only important as a business strategy, but also gives a significant contribution to the society or community, and to sustain the tourism itself as an industry. Successful CSR in Bali will sustain the company business, the society, and tourism itself as an industry. In other word, Bali tourism companies are successful when the society and tourism itself are sustainable in which CSR plays a significant role.

CSR value which sees the importance of maintaining good relationship with key stakeholders is also relevant with The Balinese philosophy of Tri Hita Karana, or three sources of harmony; harmony between human and human, human and environment, and human and God. Bali tourism industry sees CSR as "a way of saying thank you to God" (Mahyuni, 2013). As a consequence, there has been a positive trend of CSR practice by tourism companies in Bali such as hotel, restaurant, tour and travel, and tourist attractions. However, although CSR has become a common practice in Bali, studies are more focused on the implementation issues, not on communication.

A study of Bali's 26 starred hotels showed that they all had CSR reports, but 
its study objective was the CSR impacts on hotels value, not the communication aspect (Yuniarta \& Purnamawati, 2016). Another study of 30 SME companies indicated that most companies have not made CSR reports yet, only reported CSR spending through annual financial reports (Devyani, 2015). Considering the importance of stakeholders' CSR awareness but limited information found on hotels' website, Dewi, Mataram, and Siwantara (2015) designed a special website template to provide CSR information. However, there are limited studies on how tourism companies in Bali communicate CSR. There are still no studies on the goals, target audience, CSR content, use of channels, and if the companies apply any specific communication strategy.

Tourism is the backbone of Bali's economy, and the tourism companies' successful CSR positively contributes to business success, community welfare, and tourism itself as an industry. Considering the important roles of CSR and its communication for Bali tourism, a study is required on how tourism companies in Bali communicate CSR. This study was generally aimed at investigating how Bali tourism companies communicate CSR. Specifically, it investigated the goals, audience, contents, channels, and stakeholder communication strategy of communicating CSR.

\section{Methods of Research}

To gain a deep overview of how tourism companies communicate CSR, this study used a single case study approach. By case study, the research reveals the respondents' view on how their companies communicate CSR. A case study describes and analyzes a person, organization or event in details (Stacks, 2002, p. 71), to increase knowledge about real, contemporary communication events in their context (Daymon \& Holloway, 2002, p. 106), and is appropriate to answer "how and why" questions, when the focus is on a contemporary phenomenon with a real-life context (Yin, 1994). Bali is selected as the case considering its position as one of the world's best and Indonesia's most important tourist destination. Compared to other destinations in Indonesia, Bali has the most number of tourism companies and very good infra structure. There are a total of 3.894 hotels, 398 tour and travel companies, 237 tourist attraction, and 2.177 restaurants, or a total of 6.707 companies in Bali (Bali Statistics Agency, 2015). To get a complete overview, this study approaches representatives of four tourism business sectors; hotel, restaurant, tour and travel, and tourist attraction.

This qualitative study used a semistructured guided interview conducted in Bali on February - March 2017. The qualitative method is associated with the subjective nature of social reality and is well equipped to provide insights from stakeholders perspectives so that researchers can see things as the respondents do (Daymon and Holloway, 2002).

Because communicating CSR has been very little studied in Bali, individual communication and/or CSR practitioners with unique experiences and direct involvement in the field are the most credible sources. Interview is a useful form of data collection to explore the perspectives and perceptions of various stakeholders, publics and the data is situated within the respondents own social 
context (Daymon and Holloway, 2002: p.166167). The interview addressed seven questions relating to (1) Respondents and company's profile; job title, company size based on number of employees, management type and ownership structure, (2) Goals, (3) Audience, (4) Contents, (5) Channels, and (6) Strategy.

The communication strategy was explored through some questions; whether the companies gain CSR feedback from the stakeholders, who are they, using what methods, and whether they invite stakeholders to discuss CSR. The basis of the data analysis was the interview transcriptions which were uploaded to QDA Miner, a software package for coding textual data, annotating and reviewing coded data and documents (Provalis Research, 2017).

\section{Results \& Discussions}

From a total of fifty companies and business associations approached, twenty companies $(40 \%)$ gave positive responses, and thirty companies (60\%) gave negative responses, either refused to have its staff interviewed and gave no response at all. From the twenty companies with positive responses, two companies agreed to be interviewed but refused to be recorded, two interviews have broken recording files, two companies had incomplete answers, and one company provided a written answer.

There were thirteen valid interviews to be further analyzed; 2 tourist attractions, six hotels, two restaurants, and three tour and travel companies. Three interviews were conducted in English and ten were in the Indonesian language which was then translated by the author himself into English.
Ten companies were represented by one person, and two companies were represented by two people each.

All respondents held a top management position such as general manager, human resources manager, public relations manager, marketing communication manager, and CSR team manager. Six companies were categorized as large companies having more than 100 employees, seven were as medium companies having 20 - 99 employees, and no small company participated (having less than 20 employees). Regarding management, four companies operated under international chain management, two local-chain management and six were nonchain or independent management. For the ownership structure, six companies were owned by local people, three by foreign owners, three were jointly owned by foreign and local people, and one company was owned by the state or government.

This study explored the Bali tourism companies' goal, content, audience, channel, and strategy of communicating CSR. Maintaining relationship with stakeholders was the most prevalent goal to communicate CSR. Owner, employee, and society were important stakeholders with whom companies must maintain a relationship by communicating CSR. As one respondent stated;

"Of course we have to report. As our owner is a foreigner, he ought to know the purposes of the company's all social activities in the attempt to build communication with the community nearby".

One respondent also explained;

"Our main goal is that we can be closer to the community nearby so that our community will know our hotel more than before." 
Building company reputation and branding as company's intangible assets were the other two important goals. As stated by a respondent;

"...for sure the goal is to have people know that we are participating in terms of helping the community. We want to know that we helping a school. It is going to be something that people wanted to know that we are participating in empowering local people. It is more to reputation" By partly sponsoring an event in the community, we automatically promote our company, that's the goal."

It is very important for tourism companies in Bali to build relationships and gain a reputation as a CSR concerned company, especially among important stakeholders as owners, customers, and the local community. The fact that $48 \%$ of Bali hotels' CSR funds were allocated for direct community involvement indicates that the CSR goals were to maintain a harmonious relationship with, to maintain legitimacy, avoid pressure and risks, and gain support from the local community (Mahyuni, 2013). Gaining a reputation as a socially and environmentally company is because it is such a marketing tool (Mahyuni, 2013).

Studies on the audience of communicating CSR are generally through identification of specific stakeholders who are considered important by companies (Gunawan, 2008) or by the number of times specific stakeholders are mentioned in company's CSR-related documents (Global Reporting Initiative (GRI), 2015). The more often a stakeholder is mentioned in a document, the more important it is. The audience on this study was generated by directly asking to what specific stakeholders the companies communicate CSR.
Bali tourism companies communicated CSR mostly to internal, society, and marketbased stakeholders. Internally, companies communicated mostly to employees, owners, head offices, and General Manager. This finding corresponds to Goodman's (2013) study in the USA where corporations believed that corporate communication should focus on building corporate internal culture through employee engagement to gain reputation. For society, the companies mostly communicated to the local community, general public, followed by government, NGOs, and training institution. There were three stakeholders categorized as 'market'; customers, suppliers and business association.

One respondent explained the importance of communicating CSR to the owner;

"We mainly communicate and coordinate with the owner because it is related to finance. When there is a program, what it relates to, we firstly communicate it to the owner. Whatever we do we always ask for the owner's approval".

Society was the second most important audience because CSR mostly relates to supports for the local community and the general public. CSR funds of Bali hotels are mostly distributed for direct community involvement (48\%), environment (14\%), health and safety in the workplace (7\%), labour (7\%), general/miscellaneous (7\%), product (6\%), and energy (4\%) (Trianasari \& Yuniartha, 2015). As one respondent explained;

"We also communicate our programs to the community nearby and invite them to participate in the CSR activities such as the head of a local community".

Customers are also important audience because the companies expect them to be 
aware of their CSR and then to disseminate it to their relatives and colleagues as mouth to mouth promotion. Matthias (2015) believed that if the hotels CSR commitment is interpreted by guests as a real public interest, CSR has a positive impact on brand evaluation as well as on guest satisfaction and give advantages; low costs and efforts, high credibility and the crowd is used as a third-party control mechanism. Also, a study on 80 hotels in Bali revealed that customers, shareholders, employees, suppliers, community, and organizations are the most important stakeholders (Dewi, Mataram, and Siwantara (2017). One respondent added;

"Our audience is a must is our guests. So when they stay with us, they know our program, perhaps also support it, after they check out they can continue supporting us by giving the information to their colleagues".

Stakeholders' CSR concern and expectation are not only a moving target (Morsing and Schultz, 2006) but also varied across regions and industry type (Sweeney \& Coughlan, 2008). Indonesian companies' most important stakeholders are the community, shareholders, government, media, investors, customers, employee, auditor and suppliers (Gunawan, 2008). Bali tourism companies considered employee, owners, customers, and local community as most important CSR audience because of their critical roles in company operation. Communicating CSR to the employee, for instance, is "in a bid to engage them and create a stronger identification and commitment" (Crane \& Glozer, 2016, p. 18). Being asked about what content to communicate, more than half of the respondents said that they communicated nearly all CSR-related contents. As one respondent said;

"Just general CSR information. When we talk about CSR, it is always a good thing to share, right? So that is why we don't really limit that one."

However, the study showed that the companies also communicated specific themes suchas society and environment, labor practice, and product development. Contents of human rights and economic were not communicated by any company. Communication on all CSR information is generally for company owners. As one respondent said:

"We communicate finance to owners and CSR to the employee. We nearly communicate all information to owners, either it has or no financial support because it is related to our company brand name. The point is that the owner knows what the management is doing."

The interview revealed that the preferred contents to be published on the website especially on social media were related to society such as philanthropic contribution. As one respondent stated;

"What interesting to publish in social media is activities about giving donation or philanthropy. For other CSR which does seem to be interesting, we still do it but not publish it in the social media."

This finding is similar to a study that Indonesian companies mostly communicated social-related CSR information than other categories such as environmental, governance and employee (Koswara, Verity, Nugraha, \& Lukman, 2015). Another respondent believed that CSR content to be published, especially in the media, must have high news value. It was said;

"We invite media for conservation because it has high media/news value; animal release, 
animal birth, breeding and a Balinese ceremony specially dedicated for animal welfare called "Tumpek Kandang" which gain international media coverage"

In addition, CSR content must be in line with the company's CSR main focus. One respondent whose company CSR was focused on environment explained;

"Because we concern on the environment and sustainability, so we are working on that".

The contents shared to employee generally related to coordination and general announcement, as one respondent explained;

"For the employees, we just communicate when we handing our donation. We simply put pictures on what we did over there, and then small notes about the event, when was that, what did we do and we post it on notice board, and share it through email"

This study indicated that Bali tourism companies have not had any policy on content. This could be because they have limited information on which CSR information is needed by which stakeholders, that CSR is still considered simply as nonstrategic philanthropic activities, and that stakeholders rarely request for CSR data and information. When asked whether there was any stakeholders request for CSR information, most respondents mentioned "no request" while others mentioned the government, customers, and NGOs. It showed that Bali tourism stakeholders have a low concern on companies' CSR. It was only government-related agencies which sometimes requested companies' CSR data and information.

Bali tourism companies used 23 channels to communicate CSR. To communicate with internal stakeholders, the companies used report, meeting, announcement board, e-mail, and in-house communication system. Report and meeting were preferable channels to communicate with owner and employee. Companies with chain management, either local chain or international chain, were likely to have an "internal channel" with which the branch companies communicate with their head office. One hotel has a system called as 'Just Report It", more known as "intranet communication" which also gained popularity in the US as a strategic tool for internal communication (Goodman, 2013). Other channels used were a memo, press release, telephone, social media, department head, CSR involvement, training, and internal newspaper. One company explained:

"We also communicate our CSR to the employee through placing an announcement on the hotel's announcement board, through the memo to each department so that the department head will inform its employee members"

To communicate with customers, the companiesmostly used social media, employee and CSR involvement. Bali companies used specific employees to communicate CSR especially the front-line staff (of a hotel), tour guides (tour and travel) and employees who joined external CSR activities. One hotel regularly had a CSR awareness briefing with employees, especially front liners, and believed that it is these employees to communicate CSR especially to the inhouse guests. Tour and travel companies also prepared the sales people and tour guides to communicate company's CSR policy to customers. Other channels were website, brochures, magazine, newspaper, hanging flyers, CSR walls, and press release. As explained by a respondent; 
"So first we inform CSR to our employees and employee get the information and they can continue to inform the guests."

Newspaper, social media, TV, meeting and employee are used to communicate CSR to society. However, while newspaper, social media and TV were used to communicate to the general public, the companies used locally-recruited employees and believed that their CSR programs were also as channels to communicate to the local community. As one respondent said;

"We communicate to the community through our locally recruited staff because they will spread our programs to their family or community members, also with the landowner, no need for social media"

Some companies interestingly believed that they communicated through CSR implementation or participation, especially to the local community. In another word, "CSR is seen as communication, communicative events and as a forum for debates over social norms and expectations attached to corporate responsibilities" (Schultz, Castello, \& Morsing, 2013, p. 682). As one company explained;

"For the community, we communicated through supports and participation such as donating wastebasket, etc."

However, some companies argued that they did not need to communicate any CSR to stakeholders especially to the local community. Instead, they stressed the importance of CSR implementation than its communication. One respondent claimed;

"We don't need to inform our CSR to the community. They just simply know that we support and care them. Every ceremony we always donate a sum of money. That is the way we support and we do not try to announce, publish or be stand out of the crowd. The point is the community all know that we care for them."

The companies rarely published CSR information on TV, radio, and newspaper; only when the CSR has a significantly high value. Although these channels are more effective to reach a wider audience such as general public, because of the significant cost, more companies are now using websites especially social media, and face to face meeting to communicate CSR. The use of social media to communicate CSR in the tourism industry is increasing (Tomasella \& Ali, 2016).

Meeting and social media have advantages regarding more possibility for two ways interactivity which is very important in successful CSR communication (Koswara et al., 2015). The prevalent use of locally recruited employee acting as the third party expert to disseminate and endorse CSR is known as endorsed communication process through which CSR commitment delivered to public look more trustworthy and socially committed (Morsing, Schultz, \& Nielsen, 2008).

The study revealed that Bali tourism companies prevalently applied involving strategy to communicate CSR, more than responding or informing strategy (see Table 1 below). Most companies gained feedback about CSR from their stakeholders and mostly from the local community, employee, customers, and public. Face to face meeting was the most preferable method to gain feedback, along with social media monitoring, and survey. Companies had a dialogue mostly with local community 
and employee. The companies which used responding strategy gained feedback through survey and stakeholders' responses on social media (Facebook, Twitter, and Youtube). Responses such as seen or watched, liked and commented social media posts were compiled and analyzed for possible improvement on CSR. The involving strategy was found very important for successful CSR and contributes to better business operation. As one company stated;

"Every six months, community representatives pay a visit here, we share information to and through them, is there any update from the community? It is our obligation and under community rule that as a business unit we have to support community programs. So, coordination and communication are very important for better relationships",
Morsing and Schultz (2006, p.328) explained that with involving strategy, "companies engage frequently and systematically in dialogue with stakeholders in order to explore mutually beneficial action - assuming that both parties involved in the dialogue and willing to change". The importance of company - stakeholder dialogue was also supported by another respondent who explained;

"Whenever there is an opportunity as an organization, we always do a research. Like for example, like when we handle waving equipment, we went there, we will talk with the principle of the school, asking them, what kind of skills that you want your students to want to improve. We talk to them, we visited them, we ask their opinion, chat to them, and finally, they said, they start to share, said that we don't have any waving equipment."

Table 1.

Stakeholder Communication Strategy

\begin{tabular}{|c|c|c|c|c|}
\hline Company & Feedback from & Method & $\begin{array}{l}\text { Invite } \\
\text { community? }\end{array}$ & Strategy \\
\hline Attraction 1 & Public, Employee & Social Media, survey & No & Responding \\
\hline Attraction 2 & Local community & Meeting & Yes & Involving \\
\hline Hotel 1 & Local community, employee & Meeting & Yes & Involving \\
\hline Hotel 2 & None & None & No & Informing \\
\hline Hotel 3 & None & None & No & Informing \\
\hline Hotel 4 & Customers & Social media & No & Responding \\
\hline Hotel 5 & Employee & Meeting & No & Involving \\
\hline Hotel 6 & Society & Meeting & Yes & Involving \\
\hline Resto 1 & Employee, Local community & Meeting & Yes & Involving \\
\hline Resto 2 & $\begin{array}{l}\text { Customers } \\
\text { Local community }\end{array}$ & Social media, Meeting & Yes & Involving \\
\hline Travel 1 & Customers & Survey & No & Responding \\
\hline Travel 2 & None & None & No & Informing \\
\hline Travel 3 & None & None & No & Informing \\
\hline
\end{tabular}

Source; Interview transcripts 
A two-ways dialogue is very important to minimize the "communication gap" between Bali tourism companies and stakeholders because the stakeholders perceived that the companies' CSR, in some extent, did not meet with their expectation (Trianasari and Yuniartha, 2015). The problems of CSR in Bali are distribution, proposal submission, unclear criteria, possible jealousy among communities, lack of systematic and accountable report of the used CSR contribution, and the synchronization of contribution and stakeholders' needs and expectation (Dewi et al. 2015; Trianasari and Yuniartha, 2015). They found a tendency that hotels distributed their CSR funds to only certain tourist objects. Some needy communities lacked support while the others reportedly received much more CSR supports. The unclear government rules on CSR and companies' lack of CSR communications strategy are believed to be the cause of this problem (Trianasari and Yuniartha, 2015). Accordingly, companies need to adjust their communication strategy so that 'there is a balance between the private interest of the organizations with the interest of society' (Grunig, 1992) as cited in (L'Etang, Falkheimer, \& Lugo, 2007, p. 86).

\section{Conclusions}

This study indicated that maintaining a relationship with key stakeholders is the Bali tourism companies' most prevalent goal of communicating CSR. Other goals are gaining reputation and branding. The companies mostly maintain relationships with internal stakeholders such as employees, owners, head offices, and general managers. Other key audiences are the community, public, government, NGOs, training institutions, and customers, suppliers, and business associations. Regarding contents, however, Bali tourism companies did not have any specific policy on what CSR information to communicate. Instead, they communicate any CSR information. Regarding channel, Bali tourism companies consider the importance of local employees to communicate CSR to community; and tour guides and front liners to communicate with customers.

These employees have acted as "thirdparty experts" to disseminate and endorse CSR information to stakeholders (Morsing, Schultz, and Nielsen, 2008) which makes the companies look more trustworthy and socially committed. Besides, the companies also believe that CSR implementation is also a form of communication. The study revealed that Bali tourism companies prevalently applied involving communication strategy. The companies gained CSR feedback from the community, employee, customers, and public. Meeting was the preferable method to gain feedback, along with social media monitoring and survey. The prevalent use of involving strategy is a positive point because Public Relations as Indonesian company's main communication function is still regarded as a one-way communication rather than a twoway dialogue (Koswara et al., 2015).

Implementing and communicating CSR should go hand in hand to gain CSR benefits not only for the company business but also the local community and tourism industry itself. Though this study has involved four business sectors, while others generally involve only one specific sector, e.g., hotel, it still has limitations on the number of respondents 
and methodological approaches. Therefore, a further study is still needed by involving more respondents, using more data collection procedures such as quantitative survey or document content analysis.

\section{Bibliography}

Bali Statistics Agency. (2015). Statistik Daerah Provinsi Bali 2015. Retrieved from http:// bali.bps.go.id/webbeta/website/pdf publikasi/Statistik Daerah Provinsi Bali 2015.pdf

Bartlett, J. J. (2011). Public Relations and Corporate Social responsibility. In $\varnothing$. Ihlen, J. L. Bartlett, \& S. May (Eds.), The Handbook of Communication and Corporate Social Responsibility (First, pp. 67-86). Oxford: Wiley-Blackwell.

Becker-Olsen, K. L., Cudmore, B. A., \& Hill, R. P. (2006). The impact of perceived corporate social responsibility on consumer behavior. Journal of Business Research, 59(1), 46-53. https://doi.org/10.1016/j. jbusres.2005.01.001

Bhattacharya, C. B., Sen, S., \& Korschun, D. (2008). "Using Corporate Social Responsibility to Win the War for Talent." MIT Sloan Management Review, 49(2), 37-44. https://doi.org/10.1007/ s10551-008-9812-2

Coles, R., Fenclova, E., \& Dinan, C. (2013). Tourism and corporate social responsibility: a critical review and research agenda. Tourism Management Perspective., 6, 122-141. https://doi.org/http://dx.doi. org/10.1016/j.tmp.2013.02.001

Coombs, W. T., \& Holladay, J. (2012). Managing Corporate Social Responsibility A Communication Approach (First). Wiley-Blackwell.

Cornelissen, J. (2014). Corporate Communication A Guide to Theory to Practice (Fourth). London: Sage Publications Ltd.
Crane, A., \& Glozer, S. (2016). Researching Corporate Social Responsibility Communication: Themes, Opportunities and Challenges. Journal of Management Studies. https://doi.org/10.1111/joms.12196

Dawkins, J. (2005). Corporate responsibility: The communication challenge. Journal of Communication Management, 9(Cci), 108-119. https://doi. org/10.1108/13632540510621362

Daymon, C., \& Holloway, I. (2002). Qualitative Research Methods: An Introduction to Qualitative and Quantitative Approaches. London: Sage Publications Ltd.

de Grosbois, D. (2012). Corporate social responsibility reporting by the global hotel industry: Commitment, initiatives and performance. International Journal of Hospitality Management, 31(3), 896-905. https://doi.org/10.1016/j.ijhm.2011.10.008

de Grosbois, D. (2015). Corporate social responsibility reporting in the cruise tourism industry: a performance evaluation using a new institutional theory based model. Journal of Sustainable Tourism, 9582(May), 1-25. https://doi.org/10.1080 /09669582.2015.1076827.

Devyani, L. (2015). Corporate social responsibility: how to do, how much to spend and how to report? (Case studies on SMEs in Bali by using Tri Hita Karana Approach). Unpublished thesis; Brawijaya University. Available online at

jimfeb.ub.ac.id/index.php/jimfeb/article/ view/1580

Dewi, N. I. K., Mataram, I. G. A. B., \& Siwantara, I. W. (2017). Validating a framework of the integration of Corporate Social Responsibility and Culture : The Case of Hotel Industry. International Journal of Business and Economic Affairs, 2(1), 31-44. https:// doi.org/10.24088/IJBEA-2017-21005 
Du, S., Bhattacharya, C. B., \& Sen, S. (2010). Maximizing Business Returns to Corporate Social Responsibility (CSR): The Role of CSR Communication. International Journal of Management Reviews. https:// doi.org/10.1111/j.1468-2370.2009.00276.x

Fawkes, J. (2004). What is Public Relations? In A. Theaker (Ed.), The Public Relatiosn Handbook (Second). Routledge.

Global Reporting Initiative. (2015). Reporting Principles and Standard Disclosures Interpretations on the G4 Guidelines, issued by the Global Sustainability Standards Board, are located at the end of this document, and are to be considered by all users. Retrieved from https://www. globalreporting.org/resourcelibrary/ GRIG4-Part1-Reporting-Principles-andStandard-Disclosures.pdf

Golob, U., Podnar, K., Nielsen, A.-E., Thomsen, C., \& Elving, W. (2015). CSR Communication Conference 2015. In CSR Communication Conference 2015. Faculty of Social Sciences, University of Ljubljana. Retrieved from http://csr-com.org/images/ upload/proceedings_za_objavo.pdf

Goodman, M. B. (2013). CCI Corporate Communication Practices and Trends Study 2013: United States - Final Report Focus of this 2013 Briefing, (November), 1-116.

Graci, S., \& Dodds, R. (2008). Why Go Green? The Business Case for Environmental Commitment in the Canadian Hotel Industry. An International Journal of Tourism and Hospitality Research, 19(2), 251-270. https://doi.org/10.1080 /13032917.2008.9687072

Gunawan, J. (2008). Corporate Social Disclosures By Indonesian Listed Companies. Edith Cowan University. Retrieved from http://ro.ecu.edu.au/ theses/1689
Herremans, I., Pyasi, N., \& Lu, J. (2011). The Journey Toward Sustainability Reporting: How Accountable are the Tourism Industries ? Tourism Recreation Research, 36(3), 247-257. https://doi. org/http://dx.doi.org/10.1080/02508281. 2011.11081670

Holcomb, J. L., Upchurch, R. S., \& Okumus, F. (2007). Corporate social responsibility: what are top hotel companies reporting? International Journal of Contemporary Hospitality Management, 19(6), 461-475. https:// doi.org/10.1108/09596110710775129

Holcomb, J., Okumus, F., \& Bilgihan, A. (2010). Corporate social responsibility: what are the top threeOrlando theme parks reporting? Worldwide Hospitality and Tourism Themes, 2(3), 316-337. https:// doi.org/10.1108/17554211011052230

Holtzhausen, D. R., \& Zerfass, A. (2011). The Status of Strategic Communication Practice in 48 Countries. International Journal of Strategic Communication, 5(February 2015), 71-73. https://doi.org /10.1080/1553118X.2011.561092

Jahdi, K., \& Acikdilli, G. (2009). Marketing Communications and Corporate Social Responsibility (CSR): Marriage of Convenience or Shotgun Wedding? Journal of Business Ethics, 88 (1), 103-113. https:// doi.org/10.1007/s10551-009-0113-1

Kim, S., \& Ferguson, M. A. T. (2014). Public Expectations of CSR Communication: What and How to communicate CSR. Public Relations Journal, 8(3). Retrieved from http://www.prsa.org/Intelligence/ PRJournal/Vo18/No3/

Koswara, A., Verity, F., Nugraha, A. R., \& Lukman, S. (2015). Communicating CSR Practices; A Website Analysis of Indonesia's State-Owned Entities. Australian Journal of Sustainability 
Business and Society, 01(01), 27-36. Retrieved from https://www.aabss. org.au/system/files/published/000938published-ajsbs.pdf

L'Etang, J., Falkheimer, J., \& Lugo, J. (2007). Public relations and tourism: Critical reflections and a research agenda. Public Relations Review, 33(1), 68-76. https:// doi.org/10.1016/j.pubrev.2006.11.008

Lund-durlacher, D., \& Brewi, C. (2014). Implementation and Governance of Hotel Chains' CSR policies to Individual Properties. Retrieved from https://www. researchgate.net/publication/323445689 Implementation_and_Governance_of Hotel_Chains\%27_CSR_policies_to Individual_Properties

Mahyuni, L. P. (2013). An Exploratory Study of Corporate Social responsibility (CSR) in the Hotel Sector: Evidence of Drivers in Bali, Indonesia. In Brawijaya International Conference on Accounting and Business (BICAB) 2013. Malang. Retrieved from www.multiparadigma.lecture.ub.ac.id

Maignan, I., \& Ferrell, O. C. (2004). Corporate Social Responsibility and Marketing: An Integrative Framework. Journal of The Academy of Marketing Science, 32(1), 3-19. https://doi. org/10.1177/0092070303258971

Matthias, S. (2015). Change the Perspective! Successful and Efficient Corporate Social Responsibility Reporting in the Hospitality Industry. Journal of Tourism Research \& Hospitality, 10, 72-81. Retrieved from http://jotr.eu/index.php/hospitalitymanagement/109-social-responsibility

Morsing, M. (2006). Corporate social responsibility as strategic autocommunication : on the role of external stakeholders for member identification. Business Ethics: A European Review, 15(2), 171-182.
Morsing, M., \& Schultz, M. (2006). Corporate Social Responsibility Communication: Stakeholder Information, Response and Involvement Strategies. Business Ethics: A European Review, 15(October), 323-338. https://doi. org/10.1111/j.1467-8608.2006.00460.x

Morsing, M., Schultz, M., \& Nielsen, K. U. (2008). The catch 22 of communicating CSR: Findings from a Danish study. Journal of Marketing Communications, 14(2), 97-111. https:// doi.org/10.1080/13527260701856008.

Provalis Research (2017). www. provalisresearch.com.

Ricaurte, E. (2012). The Hospitality Industry Confronts the Global Challenge of Sustainability. In E. Ricauerte (Ed.), Cornell Hospitality Proceedings ( $\mathrm{p}$. 18). Cornell University School of Hotel Administration.

Schultz, F., Castello, I., \& Morsing, M. (2013). The Construction of Corporate Social Responsibility in Network Societies : A Communication View, 681-692. https:// doi.org/10.1007/s10551-013-1826-8

Seyitoglu, F., \& Yuzbasioglu, N. (2015). The Role of Strategic Communication in Hospitality Industry \&quot; The Case of Antalya \&quot; Journal of Social Science Studies, 2(2). https://doi.org/10.5296/ jsss.v2i2.6526

Stacks, D. (2002). Primer of Public Relations Research. New York: Guildford.

Sweeney, L., \& Coughlan, J. (2008). Do different industries report Corporate Social Responsibility differently? An investigation through the lens of stakeholder theory. Journal of Marketing Communications, 14(2), 113-124.https:// doi.org/10.1080/13527260701856657

Tamajón, L. G., \& i Aulet, X. F. (2013). Corporate social responsibility in tourism small and 
medium enterprises evidence from Europe and Latin America. Tourism Management Perspectives, 1-18. Retrieved from http:// www.sciencedirect.com/science/article/pii/ S2211973613000226

Tomasella, A. B., \& Ali, A. (2016). Corporate Social Responsibility (CSR ) digital communication in small independent restaurants, 1-23. Retrieved from www.academia.edu/.../Corporate Social_Responsibility_CSR_digital_ communication

Trianasari, \& Yuniartha, G. A. (2015). An Exploratory Study on the Distributions of Hotels' CSR Funds in Bali. Journal of Economics, Business and Management, 3(9), 894-897. https://doi.org/10.7763/ JOEBM.2015.V3.304

van Riel, C. B. M., \& Fombrun, C. J. (2007). Essentials of Corporate Communications (1st ed.). New York: Routledge.

Wijk, J. Van, \& Persoon, W. (2006). A Longhaul Destination:. Sustainability Reporting Among Tour Operators. European Management Journal, 24(6), 381-395. https://doi.org/10.1016/j.emj.2006.07.001.

Wong, E., Leung, R., \& Law, R. (2015). How effective are Asian hotels in communicating CSR efforts through the property websites? the case of Hong Kong. Journal of Information and Communication technologies in Tourism, 651-663.

https://doi.org/10.1007/978-3-319-14343-9_47.
World Travel \& Tourism Council (WTTC). (2015). Environmental, Social \& Governnance Reporting in Travel and Tourism trends, Outlook and Guidance. Retrieved from https:/www.wttc.org/-/ media/files/reports/policy-research/esgmain-report---web.pdf

Yin, R. K. (1994). Case Study Research: Design and Methods. (2nd ed.). London: Sage Publications Ltd.

Yuniarta, G.A., \& Purnamawati, I.G.A.(2016). Fundamental Effect of Implementation of Corporate Social Responsibility and Value Based Management on the Equity Value of Hotels in Bali. In International research Conference on Management and Business. Jakarta. Retrieved from https://www.google.de/url?sa=t\&rct= $\mathrm{j} \& \mathrm{q}=\& \operatorname{esrc}=\mathrm{s} \& \operatorname{source}=\mathrm{web} \& \mathrm{~cd}=1 \&$ $\mathrm{cad}=\mathrm{rja} \& \mathrm{uact}=8 \& \mathrm{ved}=0 \mathrm{ahUKE}-$ w j p 3 e q D s D P A h X G th Q K H W L O A w E Q I A g h M A A $\& u$ r l $=$ h t t p : / / w e b c a c he . goog leusercontent.com/ search?q=cache:ye090zAOPnkJ:ircmb. org/jurnal/Gede\%2520 Adi \%2520 Yuniarta\%2520-\%2520FUNDAMENT

Zerfass, A. (2008). Corporate Communication Revisited: Integrating Business Strategy and Strategic Communication. In Public Relations Research European and International perspectives and Innovations (pp. 65-98). VS Verlag für Sozialwissenschaften. 